\title{
Disciplining Geo-body of the Dutch Indies: Discourse Analysis on the Colonial School Textbooks of Geography
}

\author{
HOLY RAFIKA DHONA \\ Universitas Islam Indonesia, Indonesia
}

\begin{abstract}
Geography was one of the instruments the Dutch used to master the knowledge about their colonial possessions. In the Dutch Indies, geographical knowledge was developed by the Dutch colonial government and introduced to the natives through schools. The school textbooks in the Dutch colonial periods were important media for disseminating the modern geography knowledge to the natives. By analysing three geography textbooks from 1875 to 1920, this paper examines how was a new spatial mode portrayed and disseminated through colonial textbooks of geography, and how did modern geography build a new subjectivity among the colonized society. Applying Foucauldian discourse analysis, this paper aims to explicate the roles of media in producing a new spatial mode in the Dutch Indies. This study finds that geography textbooks have introduced the Hindia Netherland as a single entity under the Dutch colonial power. The textbooks, as the narrative explanation of the map, have legitimized the map as an established truth. Not only trained the natives how to read the maps, they have also trained the natives how to make the maps. They have constructed a new mode of spatiality, through which the natives were perceived as individuals, placed in and belong to certain territories, no longer related to certain rulers. The modern geography was the perfect instrument of colonial epistemological domination. It has emerged as a new knowledge or power of humans and their regions, through which the Dutch colonial government has changed the traditional 'mandala' form of power into a modern 'geo-body' form
\end{abstract}

Keywords: Geo-body, colonial geography, colonial geography textbook, colonial map, communication geography.

\section{INTRODUCTION}

On 1 July 1914, Papaes Nonoman, one of Sunda newspapers, released an article entitled "Sadjarah Pasoendan" wrote by Soeradiwidjaja. The article criticised the beliefs of the Sundanese who praised Susuhunan Solo as the ruler of the Sundanese. In fact, Susuhunan Solo was a Javanese. Soeradiwidjaja $(1914$, p. 8) noted, "There were a number of Sundanese in the villages, especially elderly people and the rich still perceived that Susuhunan Solo as their ruler. They claimed that the Dutch government ordered us because they borrowed or rented the land from Susuhunan".

Sundanese is an ethnic group in the western part of Java island, Indonesia. In the early of 20th century, as what happened in most of the Dutch Indies territories, nationalism grew within Sundanese. They began to consider themselves as a distinct nation from the Javanese (Ekadjati, 2004). It has also argued by Benedict Anderson that nationalism "... arises when, in a certain physical territory, the inhabitants begin to feel that they share a common destiny, a common future" (Anderson, 1999, p. 3). Thus, Soeradiwidjaja's article has already shown a nationalism spirit, as his idea about 'being a Sundanese' was related to certain collectivism, not to the ruler. 
I propose to read Soeradiwidjaja's text as a sign of the emergence of 'a new spatial model' against the 'traditional spatial model', in which subjectivity is determined by the ruler figures or 'men of prowess' (Wolters, 1999, p. 18). In the new mode of spatiality, the knowledge of modern geography constructs a certain territory to be the marker of one's subjectivity.

Geography, in the colonial countries, was based on colonization and was used as an instrument to control the colonized. In fact, the roots of academic geography in Netherland were intimately linked to the Dutch colonialism. Royal Dutch Geographical Society (KNAG Koninklijk Nederlands Aardrijkskundig Genootschap), Netherland prestigious institution in geography, was not an academic society in its early formation, but rather a group of people interested in the Dutch colonies.

The KNAG was initially not an academic society, but rather a group of distinguished of the army, trading companies, the shipping sector, the industrial world and government. Their main aim was the collection and development of practical knowledge about far-away place and peoples, in particular the Dutch colonies (van der Vaart, de Pater \& Oost, 2004).

Geography in the Dutch Indies seemed as a political rather than a scientific activity. By defining the new spatial knowledge with geography, the Dutch colonial government established a new form of power in which the colonial government was positioned as the ruler. The colonial school textbooks of geography have become the media to introduce this new knowledge of modern geography.

This paper aims to examine how those books, as the media, constructed a new spatial mode amongst the Dutch Indies society. Thus, this paper would answer two questions: (1) How was a new spatial mode portrayed and disseminated through colonial textbooks of geography? (2) How did modern geography build a new subjectivity among the Dutch Indies society so they recognized the territory as the boundary of their subjectivity or how this textbook disciplined 'the man of the Netherland Indies'?

However, this article is not a critic on the discipline of geography. My purpose is to describe geography as a significant instrument to produce a type of spatial model which was disseminated in the context of colonization. Also, this paper is a 'history of the present' rather than a history of the book. It aims to explain how the Indonesian modern society comprehend to the modern mode of space which was promoted by the colonial government.

Those questions do not seem to be an academic problem for the discipline of communication, especially in Indonesia and Southeast Asia. The studies about textbooks of geography during the Dutch Indies colonization are very rare. In doing so, I define communication as not solely processes of transmitting the message, but rather as processes of spatial production (Falkheimer \& Jansson, 2006; Adams, 2009; Adams, 2011; Adams \& Jansson, 2012). This kind of understanding is popular among scholars of communication geography or media geography, the new sub-field in the field of communication and media studies which concentrates on how communication produces space and vice-versa how space produces communication (Falkheimer \& Jansson, 2006). 


\section{LITERATURE REVIEW}

\section{Territory as a Modern Spatiality in the Dutch Indies}

A number of scholars have argued that territory was not an essential instrument in the formation of identity in the pre-colonial Southeast Asian. Power was not defined by fixed boundaries. In Java, power was measured based on certain units of controlled people (cacah) (Moertono, 1985; Atja \& Danasasmita, 1981). The boundaries of the kingdom were determined by the relationships between the people and the ruler, not by the territory. Commonly, this type of arrangement is defined as 'mandala polity system'. Oliver Wolters (1999, pp. 27-28) has noted, "the mandala... represented a particular and often unstable political situation in a vaguely definable geographical area without fixed boundaries and where smaller centres tended to look in all directions for security".

In this world view, the sultan/king, along with the palace, was perceived as the representation of Meru Mountain as the centre of cosmos in the Brahmanism-Buddhism system (Heine-Geldern, 1942). Further, Coedes found that, without the concept of regional borders, a kingdom in southern Malay Peninsula was included into two kingdoms at the same time. It was a country under Ayutthya kingdom (Thailand Kingdom) ruled by King Ramadhipati, at the same time became the colony of Majapahit (Javanese Kingdom) ruled by Hayam Wuruk (Coedes, 2010). It should be noted that the king in the pre-colonial era was like an omni-present God, he was everywhere and his power was unlimited by certain territories. Hans Bakker (1993), in his analysis about Java, argued that the unclear geographical boundaries have created "the importance of the conception of divine 'kingship' for securing political power and authority in Majapahit."

While, territory was used as a border by Southeast Asians when they encountered with European people. However, not many scholars attempted to explain how this transformation happened, from the traditional into the modern spatial mode. Among those few, it was an outstanding attempt from Benedict Anderson who has argued that nationalism in the post-colonial countries was formed due to imprint capitalism. He proposed the concept of 'imagined community', in which nationalism was driven by printing and language technology that homogenize the imagination of the community member (Anderson, 2001). If nationalism is about feeling to have the same territory, then the modern spatial model in the Dutch Indies was introduced by imprint capitalism.

The problem is the idea of such nationalism does not reveal the extent to which the 'boundary of nationalism' is limited. However, according to Thongchai Winichakul, Anderson's idea "help to formulate the sense of a new community in historical lineage... and the sense of homogeneous time of the new community" (Winichakul, 1994, p. 16). Meanwhile, with his concept of geo-body of nation, Thongchai Winichakul has tried to answer the problem regarding the spatial transformation. Based on a study of the formation of Thai nationalism, he concluded that Thai nationalism arouse due to spatial transformation of Thai society. The old Thai mode of spatiality, in which the power of king was more important than territory, was replaced by strict territorial boundaries as a sign of the emergence of a new modern geographical knowledge.

In this new spatial mode, human as the subject was mapped or territorialized. It was very different from the indigenous Southeast Asian tradition, in which "the subject was bound first and foremost to his lord rather than to state" (Pickles, 2004, p. 117). This new spatial mode has embodied in the Thai society and was recognised as the 'geo-body of nation' that "...occupies a certain portion of the earths surface which is objectively 
identifiable.... (it is) a man-made definite territory which has effect to people and thing and also their relationship to classification, communication and continuous reinforcement" (Winichakul, 1994, p. 17).

\section{The Colonial Schools as The Context}

Before the 1900s, the Dutch colonial did not give any attention to the indigenous education. There was a regulation about education (Isa, 1972) but only for the practical purpose, to meet staffing needs. The two early schools on teacher education were established in 1866 and 1867 (Isa, 1972). By 1900, most of schools were initiated by Protestant and Catholic missions. Moriyama stated that the colonial document, Algemeen Verslag van den Staat het Schoolvezen in Nederlandsch-Indie (AVSS), listed only 23 elementary schools in Java and Madura in 1853, then increased to 37 in 1857, 46 in 1862, 62 in 1867, and 83 in 1872 (Moriyama, 2003, p. 84). Even so, as stated in AVSS 1853, geography was considered as the basic knowledge that was necessary for indigenous people (Moriyama, 2003).

The significant increase of schools happened after the 1900s. It was recorded that the number rose dramatically from 266.000 in 1907 to 2.200 .000 in 1940 . Meanwhile, the technical college was built in 1920 and followed by law college in 1924 and medicine college in 1927.

As the Dutch colonial did not give any adequate attentions on education, indigenous were antipathetic in the beginning of colonial schools. In 1864, the natives were reluctant to send their children to school, because the school was considered as 'infidel' (Moriyama, 2003, p. 79). School was considered no better than pesantren (Islamic school), an educational institution that already existed before the Dutch arrival.

Pesantren mostly taught about religious knowledge and posited a kyai (a leader of pesantren) as the centre of knowledge. In fact, there was a different reading method between pesantren and colonial schools. In 1867, Van Der Chijs reported that the indigenous Indies read the texts in two methods of reading, namely recitation and singing (menembang). "They only used the first method only if the second method was not possible, because the second method must be very popular and regarded as the right method for them" (Moriyama, 2003). These mode of reading was a product of oral culture which had no rational objective. When colonial schools became popular in the 1900s, they provided a new mode of 'rational reading', a common way of reading in the culture of literacy. As a result, reading the book was differently experienced by the natives. The students can read the book on their own without kyai's guidance as in the pesantren. At this point, we could agree with Darnton who argued that "reading itself has changed over time" (Darnton, 1982, p. 78). Thus, colonial schools have changed the mode of reading among the natives, through which the text could be interpreted 'in the modern way'. This new mode of reading was significant instrument in disciplining the natives on geographical knowledge.

\section{Geography School Textbooks as the Instrument of Discipline}

In the communication studies, book is generally considered as a type of modern mass media. Baran (2011) has argued that book can sustain more voices in the cultural forum than other traditional mass media. Elizabeth Eisenstein believed that book played a big role in civil revolution, especially in the early days of European modernity (Eisenstein, 2005). The book, as a medium, is often used as a subject of rules/regulation (McQuail, 2010). Printed technology, including the book, in the Dutch Indies was introduced by the Dutch. It was tied 
to the existence of other social institutions, such as local libraries, the mission of the church, also the capitalization of printing by the state and private companies (Isa, 1972).

As mentioned beforehand, studies about books in the Dutch Indies colonial, within the communication and media studies, are very rarely. It might be different from a lot of research on Dutch Indies newspapers or press, particularly in the development of Indonesian nationhood (Subijanto, 2017). Even so, Zubaidah Isa's research entitled 'Printing and Publishing in Indonesia (1602-1972)' was quite helpful to decipher how the existence of books in the colonial period.

According to Isa (1972), in the VOC (Verenigde Ost Indies Company) era, books were sold by the traders as part of merchandise. Moreover in 1815, Vereeniging ter Bevordering Van de Belangen den Boekhandels (Association for the Promotion of the Book Trade Interest) was established. It was the initial moment of the book trade in the Dutch Indies. Later, the significant growth of books happened when 'Volkslectuur' (Balai Pustaka) was founded in 1910. This establishment had improved the field of publications, as well as the development of education and library. In order to guarantee the distribution and use of their publications, Volkslectuur also built several Volksbibliotheken (local libraries). The first library was built in 1911.

Physically the books for these libraries were housed in cupboards at the Inlandsche schools 2e klasse (native school, second class). The superintendents of the schools were acting librarians. Each superintendent was required to place outside the school a sign reading Volklectuur and Balai Pustaka (Association Library)... The books were meant not only for the pupils of the schools but also for the public. They could be borrowed for a small fee, depending on the kind and the size of the books (Isa, 1972, pp. 43-44).

Further, according to Isa (1972), this library supplied the reading materials for different intellectual levels. Level A was children literature in Javanese, Sundanese, and Madura languages. Level B was fiction and non-fiction literature or recreational literature. Level $\mathrm{C}$ was advanced literature in Malay/Bahasa Indonesia.

As a subject of colonial school regulations, school textbooks were a disciplinary instruments in the Dutch Indies. They were closely tied to the discipline of colonial citizenship knowledge. According to Foucault, discipline "makes individuals; it is specific technique of a power that regard individuals both as objects and as instruments of its exercise" (Foucault, 1977, p. 170). Arun Saldanha stated that the books were the effective tools as a learning knowledge because it has the openness and the newness to the things that are 'taken for granted' by a society (Saldanha, 2011). Books were an important media to deliver a new episteme, a new knowledge, including the modern geography. Colonial school textbooks of geography became disciplinary spaces, in which the indigenous subjects become the objects of a new mode of spatiality. In this sense, geography became a significant knowledge as it helped to formulate a new model of power. Following Saldanha "the geographical imagination, as given in official documents, books, and other texts, is fundamental to the mechanisms of European colonization" (Saldanha, 2011, p. 151). 


\section{METHOD}

The materials of this study are three colonial geography textbooks written in Malayan language which were published around 1860 - 1920. The first is I/moe Boemi (Earth Science) written by Harmsen L. K., published by Ogilvie Batavia in 1875 (Harmsen, 1875). The second is the fourth edition of Dari Tanah Hindia Berkeliling Boemi (From the Indies around the Earth) by W. Van Gelder, published in 1904. The third is ilmoe Boemi (Earth Science) by F.B. Sanders, published in 1920 (Sanders, 1920).

The books are treated as a discourse, 'a practice/statement that is regulated' (Foucault, 1972, p. 80). Further, Andersen proposed that Foucault discourse analysis consists of four stages, namely the archaeology of knowledge, genealogy, self-technic analysis, and dispositive analysis (Andersen, 2008, p. 7). Meanwhile, this study only deals with the archaeology of knowledge, which is an analysis about the regularity of discourse in the distribution of statements.

The analysis was conducted by close-reading of all statements in the textbook. From this reading, I described how the order of discourse in these books formed a new spatial knowledge and its disciplines. This archaeological description was carried out with two principles in Foucauldian discourse analysis, namely non-interpretive and nonanthropologist (Kendall \& Wickham, 1999). Non-interpretive means that archaeological analysis avoids judgements. By this principle, archaeological analysis provides no more than a description of regularities, differences, transformations. Non-anthropologist means eschewing the search for authors and concentrating instead on statements and the visibilities. Kendall \& Wickham $(1999$, p. 26) stated that the principle of non-anthropologist "...exhorts us to concentrate on the appearances of statements and by implication to avoid the habit of seeking to source meaning in human beings".

\section{RESULTS AND DISCUSSION}

In this section, I will discuss two themes as the exploration of the two research questions. At first, I will discuss how the native 'place of live' was represented in the colonial geography textbooks and how this representation has in turn constructed a new spatiality and territorial-based subjectivity. In the second part, I will discuss how the colonial government, through the geography textbooks, disciplined the natives with this new mode of spatiality.

\section{The Construction of Territories of the Dutch Indies}

The three textbooks always explained that the student was learning about 'Hindia Holland' or 'Hindia Netherland'. But what is the 'Hindia Netherland'? Haßrmsen (1875) stated that it was the land of Hindia which is consisted of two major islands, i.e. Sunda Island and Maluku. Sunda Island is divided into Sunda Major (Sunda Besar), consisting of Sumatra, Java, Borneo, and Sulawesi, meanwhile Sunda Minor (Sunda Kecil) was Ambon Island, Banda and Ternate. This category was followed by another two books.

In the narrowest scale, those authors usually divided the territories into territorial administrative, especially using colonial administration terms, such as 'resident', 'assistant resident', or 'regent'. For example, Harmsen (1875, p. 25) wrote, "Lake Toba in Batak. Lake Manindjoe in Residentie Padangsche Bovenlanden, ... Lake Singkarak in Residentie Padangsche Bovenlanden ... Lake Ranau in Residentie Palembang". Whatever kinds of territorial elements and scales used in those books, the gaze was constructed from a "Hindia Netherland' perspective. The authors have constructed the unification of regions called as the Netherland Indies that were actually separated. 
Previously, the indigenous people, from Aceh to Papua, realized that they were separated into several nations and kingdoms. Under the same name 'Hindia', they were transformed as a singular entity. "Hindia" was imagined as a single entity due to the assumption that some regions could be combined into one because they were subjected to one power over these regions, that was the Netherland.

Harmsen (1875) stated that the "Hindia" land was one entity as "the East Hindia Island" which was parallel to countries in the Asian continent. From Asian regional view, he then explained the parts of Dutch Indies. Gelder (1904) took a different way. He started with explaining the land of Hindia without making any comparisons to other parts of Asian continents. Gelder unified the 'Hindia' by making a centre of all territories, that was the land of Java. In the introduction of his book, Gelder (1904) emphasized, "...in this book, the land of Djawa was discussed first, it was because the Djawa was the centre of other islands in the Hindia Netherlands; besides that, it was the place of the big ruler (Toean Besar) and other notable government administrators".

Sanders (1920) also started with the explanation about Java island with the similar reason as Gelder's idea. Java was the most important island in the Dutch Indies, and the most populated as well. Besides, it had big cities and crowded bandar or trading ports. "In the outside of Java island, there were a small number of a big or crowded countries, such as Padang, Medan, Ambon, Menado, and Bandjarmasin" (Sanders, 1920, p. 9). Another interesting reason was, "Java island was inhibited by more civilised people compared to other part of the Dutch Indies (Minahasa nation was 180.000 people, as the exception)" (Sanders, 1920, p. 9).

The textbooks also represented a significant change in describing the territory of Netherland Indies. After the 1900s, there were attempts to make Java as the centre of Netherland Indies which was perhaps related to the increase of colonial control over the Dutch Indies. In the early of 20 century, the trading activities increased significantly, "There were doubled exported product in the first decade of the 20 century, and increased eightfold in 1920" (Shiraishi, 2005, p. 36). Therefore, Gelder and Sanders were focused in Java island. In fact, a half part of Sanders's book has described about Java.

However, in the third decade of twentieth century, the Indies nationalists named the entire Netherland Indies as "Indonesia." The term Indonesia was derived from 'Indu-nesian', which was originally created by British travellers in 1850 s and popularized mainly by British scholars (Elson, 2009). In this sense, the indigenous' declaration to become 'one Indonesia' as represented at the Youth Pledge 1928, was another result of the success of the unification of the entire Netherland Indies territories by the colonial government.

The Dutch Indies geography textbooks introduced the territory with certain characteristics, such as natural conditions, vegetation, mountains, culture, and others. Even though they have discussed many things, they have focused on two main dimensions: human being and a territory, a certain area on the earth. The territorial dimensions were discoursed through several knowledge, such as 'political/administration knowledge' as represented by the terms of resident, assistant resident, or regent; or 'botanical knowledge', such as area for nutmeg producers. While the dimensions of human were discoursed through ethnological knowledge, such as certain groups of people more civilized than another groups; or historical knowledge, such as the history of the Dutch in Java; or linguistic knowledge, for example the Dutch Indies language came from the Malay Polynesian language. 
The unique character of the Dutch Indies colonial geography was to form the geobodies as 'multiple subjects', which means an individual who identified (or subjected) by varieties of modern knowledge. A person, at once, could be an individual of a particular resident, as a subject of administrative knowledge, and be a member of a particular language group, as a subject of linguistic science. Even though this multiplicity allowed the variation of subjectivity, it was bounded with 'a dominant boundary of territory' made by the colonial government, that was 'the Netherland Indies'.

In this discursive mode, the traditional political and cultural authorities were excluded. In the textbooks, Yogyakarta and Surakarta, two old kingdoms in Java, were defined only as territorial administrations. The traditional rulers were only bounded with their territories and not with the whole Javanese people. The people were no longer discussed with traditional authority, but differentiated by the regions, whether administrative or cultural regions. In this sense, Soeradiwidjaja, a Sundanese writer whose text I quoted at the opening of this paper, comprehended that Surakarta authority was merely about Javanese authority. The land of Sunda and its people, according to Soeradiwidjaja, was an independent nation from Java, but under the authority of residents in the Sunda regions.

Census, a technique developed by the modern statistic, became another mechanism to attach the native to the territorial and cultural boundaries. Native was a group of population in a 'territorial scale' or 'cultural scale'. For example, Gelder mentioned in the 1900s, Java island was inhabited by twentyeight and three quarters of million people. According to him, in Java island there was 620.000 of white people, 277.000 Chinese, and 180.000 Arab. Meanwhile, the remaining of 28.5 million were indigenous, consisting of Javanese 19.5 million, Sundanese 5.5 million, and Madura 3.5 million (Gelder, 1904, p. 28).

Benedict Anderson (2001) believed that there was a quantification of people in the traditional system of power but limited to concrete purpose. This could be traced, for example, in the tax payer notes and records to the kingdom. Radin Fernando stated that Vereenigde Oostindische Compagnie (VOC) had ever held a survey in 1686 but they only focused on 'cacah', which is a traditional unit of quantification for people based on family, not individual (Fernando, 2013, p. 4). Thus, according to Anderson, the significant element in the colonial census was the 'systematic quantification' of people which began after the 1850s (Anderson, 2001, p. 251). In this new kind of census, the colonial government even counted women and children that were not counted in the traditional account (Anderson, 2001).

The new colonial census has marked the emergence of 'common/ordinary people' in the system of knowledge, as 'an individual'. In the traditional authority, ordinary people were never being discoursed as individual. Most of the traditional manuscripts, for example Babad Tanah Jawi (Santoso, 1979) only contained the narrations of the ruler and his family genealogies. Thus, the census has cut the power relations between traditional rulers with the common people, and has placed all the indigenous within territory as part of it. If the Mercatorian map was the mapping of the earth, then perhaps census was the mapping of human.

\section{Disciplining The man of the Netherland Indies}

Harmsen $(1875$, p. 1) has defined Ilmoe Boemi (Earth Science) as: "every single things of the earth and all of the water surroundings. Therefore, there are some discipline you may learn from this subjects, such as: in what part of the world there is a land and where large water 
collection is found and whose name and where part of the earth you live". Harmsen has defined geography as a science which learn about every detail of the earth as a place for human being. The territories of the earth have their own name and they are not related to the leader, as perceived in the traditional knowledge. The world is no longer understood as the order of macrocosm-microcosm. Ilmu Boemi has taught the indigenous about a new spatial knowledge and a new imagination of the world.

In this imagination, the map has an important function to define the world and the subject in it. Harmsen (1875, p. 6) noted, "Accordingly, what explain this lesson were the earth maps that have been described by people". The map referred by Harmsen was the European map which is the Mercatorian map that depicted the world with a cylindrical shape of the earth. Map was a visualization of the earth territories in a smaller scale, whether it was precise or not, complete or not.

A map as a representation of pictorial land and water is a new thing for the local people. Most of kingdoms or traditional rulers in Southeast Asia did not leave the maps as the instrument to convey the boundaries of power. Svan Langguth who wrote about the creation of Sundanese map, found out that "most maps were drawn up in Europe but based on the geographic description provided by text account" (Langguth, 2012, p. 241) The map of Sunda/Java was initially narrated by Summa Oriental written by Tome Pires around 1511 - 1515. In Thailand, Winichakul (1994) stated that until 1851 there were only two types of maps that always have local characteristics and never designated in a broader scale. With the absence of maps in the indigenous discursive, the relations between colonial geography textbooks and maps were:

In terms of communication theories and common senses, a map is a scientific abstraction of reality.... this relationship was reversed. A map anticipated spatial reality not the vice versa...A map was a model for, rather a model of, what it purported to represent...A map was now necessary for the new administrative mechanisms and for the troops to back up their claims (Winicakhul, 1994, p. 310).

Even so, Denys Lombard, the French historian, believed that the native of the archipelago had "... a geographical map which provided the earth overview that was less comprehensive but more precise, less stylish but more suitable for the success to control the better world" (Lombard, 1996, p. 205). Along with Lombard, Resink also believed that maritime communities in archipelago such as Makassar had the map (Resink, 2012). However, even if the indigenous map existed, it was not the same with European map, in its form, technique and epistemological reason. It had possibly only local characteristics as set in the mandala world view.

The map was a new image of the world which was explained in detail in the colonial geography textbooks. Map as a visual description of human place was also represented in "Dari Tanah Hindia Berkeliling Boemi" (From the Indies around the Earth) by Gelder (1904). This book mentioned an order to regularly check the map if there was geographic phenomena in the narrative explanation. The textbook of geography was an explanatory narrative of map with more complex and detail explanations. In this notion, Ilmoe Boemi was an instrument of the Dutch Indies colonial government to place indigenous people as subject in this new image of the world which was not defined by the king, but by the 
territory. It has also positioned the indigenous as the object of cartography, a knowledge of practical map making.

The map itself, according to Anderson (2001), was a representation of colonial territories which was continuously developed as it depended on the political dynamics. It was directly related with the colonial territories expansions made by agreements and wars. This continuous formation of the colonial territory was also represented in the textbooks. Harmsen (1875) and Gelder (1904) have described Batak Land (now is North Sumatra Province, Indonesia) was a country that had not been subdued under the Dutch rule. Therefore, the story of the Batak was very limited. However, in Sanders (1920), Batak had already included in the part of Tapanuli residency. This conquest, Sanders wrote, was designated in order to civilize Batak people, "It was a common label that Batak people often screwed up and ate human, but in this period the people had already civilized" (Sanders, 1920, p. 143).

Meanwhile, the textbooks have also disciplined the student to believe the map as the only imagination of the world. It was upheld by the method of confirming narration in the geography books with the maps. It was also common to talk about the earth and its contents with map as a reference. In the introduction, Gelder (1904) noted, "At first, the teacher teaches the lesson while explaining the content of the book. Then, the students comprehend the lesson by using an atlas at home. In the following days, the students could explain about any countries, rivers, and other components on the big map".

In order to discipline the students in comprehending the territory and its varieties, the colonial geography textbooks have developed a hierarchy of learning based on the scale of territories. The natives taught how to recognise the territory from the small to the wider area, which also means that the body was attached to a smaller place then continued to the wider residency. In the second year (second grade), students had been taught the knowledge of the residency and the village they lived in. Gelder who has written for the third grade students claimed his book as a book about the 'whole land of the Netherlands Indies' in a more detailed. He assumed that the students have already learned the residency. Thus, in Gelder's book, students were created to become 'geo-bodies of the Netherlands Indies', after had been previously trained to become subject of certain residencies. Through this kind of discipline, Sanders had a confidence to write that the entire population of East Indies could be referred to as the "Netherlands Indies".

This discipline was not only embodied by testing the student ability to point out certain locations on the map, but also by testing the student ability to draw maps. Gelder (1904) mentioned, "It was suggested that the students drew the map being discussed". In the first lesson, the students only had to draw the small elements of the map, such as the border. Then, the students had to draw bigger elements, such as the bay or the cape, and as the result the students could draw an island. In the next examination, the students had to draw a territory based on their memory. Gelder (1904) has emphasized in the introduction, "Thus, when the material had been taught entirely, the students drew a map based on their memory in order to assure that they memorised it strongly". Accordingly, the colonial geography textbooks have trained native students to be 'colonial cartographer'.

It shows that Ilmoe Boemi textbooks have served to legitimize the map as an established truth. The imagination of the world with the territorial based of spatiality was not debatable. The indigenous perception about the world was controlled by the Dutch colonial government, the master of map. It confirms Anderson's idea that "The Mercatorian 
map, brought in by the European colonizers, was beginning, ... to shape the imagination of Southeast Asians" (Anderson, 2001, p. 262).

While, in order to construct a man of 'Netherland Indies', colonial geography textbooks also used the language as a cultural boundary of the native subject. Sanders wrote that the Netherland Indies language was Malay:

It had been determined by educated people that all the languages used in the land of the Netherlands Indies (except the land of Papua) were the same as they came from. It was because all languages were given the same name, namely Melajoe-polynesian languages.... Moreover, it was alleged that the wise person in linguistic stated that all the Indies were originally from the Back Indies, perhaps from Cambodia or Cochin China or Anam (Sanders, 1920, p. 7).

A year before Sanders's book published, in 1919, the Volkslektuur (Balai Pustaka) has officially published Malay-language literature. Previously, the colonial government considered that many Dutch Indies people did not understand the Malay language. Isa $(1972$, p. 8) has noted, "The Malay language spoken by the Javanese was less subtle ... but on the Riau islands, in Melaka and on the Lingga islands, people used the Melayoe Haloes language, called 'Malay Riau'. The Dutch government had determined that all books for schools must be written in the Riau way". Sanders' book stated that Malay language, which was later recognized as Indonesian, was determined on the consensus held by the colonial. Linguistic knowledge was used to identify the man, but the man had been mapped and constructed as a geo-body. At the first, Dutch Indies colonial connected indigenous with a fixed area of the Netherland Indies, then they identified people with various identities, including language.

Some scholars with a nationalist perspective have argued that Indonesian language was originally developed by the Indonesians, not the colonial. They stated that Bahasa Indonesia was derived from Melayu Rendah language (Low Melayu) which has resisted colonial regulation in using Melayu Tinggi (High Melayu). In this case, Hilmar Farid (1994) argument that Indonesian language is "the result of nationalism or more precisely; the concept of the Indonesian nation" is worthy to note. I agree with this idea, but with more emphasize that Indonesian language was colonial product. Even though the Indonesian language has resisted the colonial regulations, it was unable to surpass 'language boundaries' which follows the 'Netherland Indies' territories constructed by the Dutch colonial government.

In the Netherland Indies, many 'ethno-nationalism' have emerged in the second decade of the twentieth century (Elson, 2009, p. 47). The regional (etno-nationalist) organizations have risen this kind of nationalism. For example, Boedi Oetomo brought Javanese nationalism, Paguyuban Pasundan defended Sundanese nationalism, and others. Although it seemed that ethno-nationalism was based on cultural identity, it actually grown first from the 'national boundary' which was produced from the territorial arrangement. In another word, this was also another product of the new geographical knowledge.

An example of this case was Sundanese nationalism, which has included Cirebon and Banten communities, two regions that were culturally different from Sundanese. However, the cultural differences were then acceptable because Banten and Cirebon belong to the 
Sundanese territory according to the colonial government. There was a story from the meeting for the declaration of the official Sundanese language (hoof-dialect) held in Serang, Banten. Djajadisastra (1915) in his article questioned Serang was not Sundanese territory, so it was not feasible to be a place for determining the identity of Sundanese. It shows that the Sundanese territory given by the colonial was important in the matter of determining the identity of the Sundanese nation.

\section{CONCLUSION}

This study has found that the colonial geographic textbooks have introduced a new knowledge that "Hindia Netherland" was a single entity due to the assumption that they were subjected to one power over the regions, that was the Netherland. The books usually divided the territories based on certain colonial administrative purposes, such as resident and regent. In this new spatiality, the traditional political and cultural authorities were excluded. People were no longer related to the traditional authorities, but differentiated by the regions.

The textbooks of geography in the Dutch Indies colonial were the media for disseminating modern geography knowledge as recognized by Indonesians today. They, along with modern Mercatorian map, had important functions to define the world. The textbooks did not only explain the map with the description, but they have fundamentally legitimized the map as an established truth. In this notion, modern geography was the perfect instrument of colonial epistemological domination. It had given a fundamental tool to the Dutch colonial government to construct indigenous people as the subject in this new image of the world which was defined by the territory, not by the king.

In order to discipline the students to believe the map as the only imagination of the world, the textbooks have emphasized to confirm the narration in the geography books with the maps. The books have also developed a hierarchy of learning based on the scale of territories, through which the students learn how to identify the territory from the small to the wider area. In this way, the students were first trained to become the subject of certain residencies, then they were created to become 'geo-bodies of the Netherlands Indies'. Moreover, not only trained the students how to point out certain locations on the map, the books have also trained the students how to draw maps, the images of the world that they have just known.

The modern geography represented in the textbook have also changed the natives into individuals, as well as into 'multiple subjects'. However, the multiplicities were bounded with 'a dominant boundary of territory' made by the colonial government. By changing the mode of spatiality, the Dutch colonial government had also changed the form of power, from 'mandala polity' form of power to the modern geo-body form of power.

Based on these conclusions, this study suggests for the future research to examine how the role of media in constructing territory in other Southeast Asia countries, or generally in any postcolonial countries. It will also be important to examine how the digital media affect the modern spatiality, whether they strengthen the territorial-based spatiality or offer a new mode of spatiality. 


\section{ACKNOWLEGDEMENT}

Special thanks to DPPM Universitas Islam Indonesia for funding this research, Luthfi Adam (Arryman Fellowship of Northwestern University) for his advice in treating the historical data, also the reviewers and editors who have provided meaningful reviews and comments on this paper.

\section{BIODATA}

Holy Rafika Dhona is a lecturer at the Communication Department, Universitas Islam Indonesia. His academic interest includes communication and media geography. Email: holy.rafika@uii.ac.id 


\section{REFERENCES}

Adams, P. C. (2009). Geographies of Media and Communication: A Critical Introduction. Chichester: Wiley-Blackwell.

Adams, P. C. (2011). A taxonomy of communication geography. Progress in Human Geography, 35(1), 37-57.

Adams, P. C. \& Jansson, A. (2012). Communication geography: A bridge between disciplines. Communication Theory, 22(3), 299-318.

Andersen, N. A. (2008). Discursive analytical strategies: Understanding Foucault, Koselleck, Laclau, Luhmann. Bristol: Policy Press.

Anderson, B. R. (1999). Indonesian nationalism today and in the future. Indonesia, 67, 1-11.

Anderson, B. R. (2001). Imagined communities: Komunitas-komunitas terbayang. Yogyakarta: Insist Press \& Pustaka Pelajar.

Atja, \& Danasasmita, S. (1981). Sanghyang siksakanda ng karesian; naskah sunda kuno tahun 1518 Masehi. Proyek Pengembangan Permuseuman Jawa Barat.

Bakker, J. H. (1993). The Hindu Javanese world view in Java: The structural roots of the Pancasila state. Proceeding of the 21st Meetings of the Canadian Council for Southeast Asian Studies. The University of Alberta.

Baran, S. J. (2011). Introduction to mass communication: Media literacy and culture. New York: McGraw-Hill.

Coedes, G. (2010). Asia Tenggara masa Hindu Buddha. Jakarta: KPG, Ecole Francais d'Extreme-Orient, Forum Jakarta-Paris, Pusat Penelitian dan Pengembangan Arkeologi Nasional.

Darnton, R. (1982). What is the history of books?. Daedalus, 111(3), 65-83.

Djajadisastra. (1915, April 30). Kikintoen ti pagoenoengan. Papaes Nonoman, p. 4.

Eisenstein, E. (2005). The printing revolution in early modern Europe. New York: Cambridge University Press.

Ekadjati, E. S. (2004). Kebangkitan kembali Orang Sunda: Kasus Paguyuban Pasundan 19131918. Bandung: Kiblat Buku Utama.

Elson, R. (2009). The idea of Indonesia: Sejarah pemikiran dan gagasan. Jakarta: Serambi Ilmu Semesta.

Falkheimer, J., \& Jansson, A. (2006). Geographies of communication: The spatial turn in media studies. Göteborg: Nordicom.

Farid, H. (1994). Menemukan bangsa, mencipta bahasa: Bahasa, politik, dan nasionalisme Indonesia. Jurnal Kalam, 3.

Fernando, M. R. (2013). Sebuah daftar masa lalu terkait desa, kepala desa, rumah tangga, upeti dan penghasilan di Priangan, Jawa Barat, 1686. In Khazanah Sejarah Indonesia dan Asia-Eropa dari Arsip VOC di Jakarta, Dokumen 11. Jakarta: Arsip Nasional Republik Indonesia.

Foucault, M. (1972). The archaeology of knowledge. New York: Pantheon Books.

Foucault, M. (1977). Discipline and punish: The birth of the prison. New York: Vintage Book.

Gelder, W. (1904). Dari tanah Hindia berkeliling boemi: Kitab pengadjaran ilmoe boemi bagi sekolah anak negeri di Hindia Nederland. Groningen: Gedrukt Bij J. B. Wolters.

Harmsen, L. K. (1875). Bahoewa ini ilmoe boemi ija-itoe pada menjatakan perihal tanah kepoelauwan Hindija di sabelah Timor jang di bawah perentah goewernemen Holanda. Batawi: Ogilvie.

Heine-Geldern, R. (1942). Conceptions of state and kingship in Southeast Asia. The Journal of Asian Studies, 2(1), 15-30. 
Isa, Z. (1972). Printing and publishing in Indonesia 1602-1972 (Doctoral thesis, Indiana University).

Kendall, G., \& Wickham, G. (1999). Using Foucault's methods. London: Sage Publications.

Langguth, S. (2012). Thinking in islands: The Portuguese perception of the Indonesian archipelago and particularly of Sunda in early texts and charts. Wacana, 14(2), 241264.

Lombard, D. (1996). Nusa Jawa: Silang budaya, kajian sejarah terpadu. Jakarta: Gramedia Pustaka Utama.

McQuail, D. (2010). McQuails mass communication theory. London: Sage Publications.

Moertono, S. (1985). Negara dan usaha bina-negara di Jawa masa lampau: Studi tentang masa Mataram II, abad xvi sampai XIX. Jakarta: Yayasan Obor Indonesia.

Moriyama, M. (2003). Semangat baru: Kolonialisme, budaya cetak, dan kesusastraan Sunda abad 19. Jakarta: Kepustakaan Populer Gramedia.

Pickles, J. (2004). A history of spaces, cartographic reason, mapping and the geo-coded world. London: Routledge.

Resink, G. (2012). Bukan 250 tahun dijajah. Jakarta: Komunitas Bambu.

Saldanha, A. (2011). The itineraries of geography: Jan Huygen van Linschoten's itinerario and Dutch expeditions to the Indian Ocean, 1594-1602. Annals of the Association of American Geographers, 101(1), 149-177.

Sanders, F. (1920). Tanah Hindija Nederland, Oentoek sekolah pengadjar (Normaal School) dan Iain-lain Sekolah Boemipoetera di Tanah Hindija Nederland. Weltevreden: N.V Uitgevers Mij 'Papyrus'.

Santoso, S. (1979). Babad tanah Jawi (Galuh Mataram). Surakarta: Citra Jaya.

Shiraishi, T. (2005). Zaman bergerak: Radikalisme rakyat di Jawa 1912-1926. Jakarta: Grafiti. Soeradiwidjaja. (1914, July 1). Sadjarah Pasoendan. Papaes Nonoman, p. 8.

Subijanto, R. (2017). Enlightenment and the revolutionary press in colonial Indonesia. International Journal of Communication, 11, 1357-1377.

Winichakul, T. (1994). Siam mapped: A history of the geobody. Honolulu: Univ. of Hawaii Press.

van der Vaart, R., de Pater, B., \& Oost, K. (2004). Geography in the Netherlands. Belgeo, 1, 135-144. Retrieved from https://journals.openedition.org/belgeo/10076

Wolters, O. W. (1999). History, culture and region in Southeast Asian Perspectives. Singapore: Seng Lee Press Pte Ltd. 